
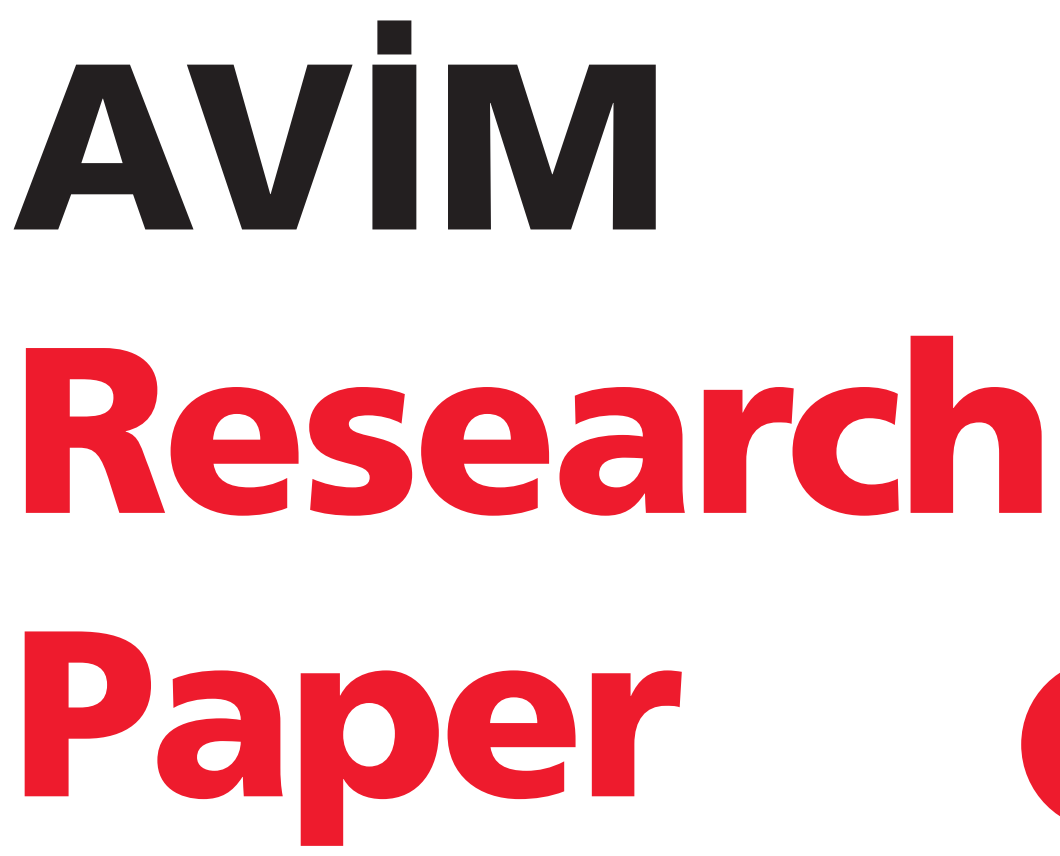

\section{Teoman Ertuğrul TULUN}

Center For Eurasian Studies (AVIM) DOI: 10.31219/OSF.IO/DPQS4
DEGENERATING DISCURSIVE ATTEMPTS IN THE BALKANS TO ALTER THE LEGAL DEFINITION AND CONTENT OF THE CONCEPT OF GENOCIDE

\section{Introduction}

The term genocide reflects a legal concept. Raphael Lemkin, a Polish lawyer of Jewish ancestry, coined the term in 1944. The period in which Lemkin coined the term coincides with the Second World War. After the occupation of Poland by Nazi Germany, Lemkin left the country via Sweden, came to the USA on 18 April 1941, and joined the law faculty at Duke University in North Carolina. Duke University appointed him as a lecturer in comparative law in the Law School. In June 1942, the Board of Economic Warfare and the Foreign Economic Administration in Washington, D.C., hired him as chief consultant, and in 1944 the U.S. War Department brought him on board as an international law expert. ${ }^{1}$

1 Samantha Power, A Problem from Hell: America and the Age of Genocide (New York: HarperCollins, 2007), chap. 2. 


\section{DEGENERATING DISCURSIVE ATTEMPTS IN THE BALKANS TO ALTER THE LEGAL DEFINITION AND CONTENT OF THE CONCEPT OF GENOCIDE}

He started to write his most significant work, Axis Rule in Occupied Europe, in 1942. He formulated his work in Nazi Germany's and other Axis Power's occupation policy especially in Poland and the Soviet Union. As per his thinking, Germany ignored "the rules and customs of international law, which had evolved since the second half of the eighteenth century," and constructed its laws on the basis that "what was useful and necessary for the German nation" was the rule of law. ${ }^{2}$ Lemkin propounded that "German law was used as an instrument of oppression to subjugate the population in occupied lands." Besides, certain biographers report that following the German invasion of Russia, "the Einsatzgruppen killed 2,000 Jews in Bialystok on 27 June and another 7,000 in Lviv... (and) by the end of the year, they and their Romanian allies killed 600,000 Jews. "They assert that these persecutions of Jews had a profound effect on Lemkin's formulations of the concept of genocide. ${ }^{3}$ For his book, Axis Rule in Occupied Europe, The Carnegie Endowment for International Peace (CEIP) in Washington provided Lemkin with office facilities for a year, the services of a shorthand typist, and research and editorial assistance. ${ }^{4}$

After the particular controversy between Lemkin and CEIP on the financial details, the book Axis Rule in Occupied Europe: Laws of Occupation. Analysis of Government. Proposals for Redress was published in Washington towards 1944, although his preface was dated a year earlier, 15 November 1943. It was a volume of almost seven hundred pages. Lemkin analyzed the occupation laws in terms of the techniques developed by the Germans for subjugating conquered peoples in part of the book. Certain parts of the book also dealt with the impact of the occupation regulations on a country-bycountry basis, including Albania, Austria, the Baltic states of Lithuania, Latvia, and Estonia, Belgium, ex-Czechoslovakia, France, Denmark, Greece, Luxemburg, the Netherlands, Norway, and Poland. Half of the Book contained an English translation of the German decrees. Lemkin's central insight was to deduce from these occupation regulations that the Germans intended to reorganize Europe along racial lines, which would entail mass murder and the suppression of other cultures. Lemkin argued that large areas of occupied Europe, including western Poland, Luxembourg, and certain Yugoslav provinces, were incorporated into the Reich, and that certain land in the East was reserved for colonization and the Lebensraum. He asserted that this policy was in contravention of international law and implemented by mass deportations of native populations to make room for the settlement of German colonists coming into new areas in the occupied countries and by liquidating owners of business enterprises and putting Germans in their place. As a result, Poland, Ukraine, and portions of Russia were tapped for raw materials, food, and labor. ${ }^{5}$

The core of Axis Rule in Occupied Europe was a chapter (Chapter IX / Genocide- A new Term and New Conceptions for Destruction of Nations) dealing with genocide. He explains that by "genocide," he means the "destruction of a nation or of an ethnic group." Lemkin further notes that the term he coined denotes "an old practice in its modern development, is made from the ancient Greek word genos (race, tribe) and the Latin cide (killing), thus corresponding in its formation to such words as tyrannicide, homicide, infanticide, etc." ${ }^{6}$ Finally, at the end of chapter IX, Lemkin, under the rubric of "Recommendations for the Future", proposes to review and consider the place of genocide in the present (mentioning 1944's) and future international law in the light of the German practices of the present war, that is the Second World War.

As per the scholarly sources, Lemkin was deeply disappointed by the judgment delivered against the accused at Nuremberg on 1 October 1946. He was particularly displeased with the judge's failure to

2 J. Cooper, Raphael Lemkin and the Struggle for the Genocide Convention, 2008th edition (Basingstoke England ; New York: Palgrave Macmillan, 2008), 53.

3 Cooper, 45,54

Cooper, 54.

Cooper, 56.

6 Raphael Lemkin, Axis Rule in Occupied Europe: Laws of Occupation, Analysis of Government, Proposals for Redress, 2nd edition (Clark, N.J: The Lawbook Exchange, Ltd., 2008), 79. 
include the concept of genocide. By the spring of 1946, Lemkin modified his initial proposals on genocide formulated in the Axis Rule in Occupied Europe and advocated that the newly formed United Nations should sponsor a treaty to prevent genocide and use its machinery to enforce it. Scholarly manuscripts on his such proposals appeared in France in the influential Revue Internationale de Droit Penal, a journal, the Bulletin de la Commission internationale penale et penitentiaire and in Belgian and Norwegian law journals. Lemkin also addressed the Cambridge conference of the International Law Association in August 1946 and put forward the same plan. ${ }^{7}$

On December 11, 1946, one year after the final armistice, the UN General Assembly unanimously passed a resolution which stressed that "The punishment of the crime of genocide is a matter of international concern," and affirmed that "genocide is a crime under international law which the civilized world condemns, and for the commission of which principals and accomplices whether private individuals, public officials or statesmen, and whether the crime is committed on religious, racial, political or any other grounds - are punishable." Resolution also requested the Economic and Social Council "to undertake the necessary studies, with a view to drawing up a draft convention on the crime of genocide to be submitted to the next regular session of the General Assembly."

In the ensuing period, The Convention on the Prevention and Punishment of the Crime of Genocide (Genocide Convention) was adopted by the General Assembly of the United Nations on 9 December 1948. ${ }^{9}$ From this point of view, the Genocide Convention ${ }^{10}$ is an instrument of international law that codifies the crime of genocide. In this regard, the Genocide Convention is also the first human rights treaty and signified the international community's commitment to 'never again' after the atrocities committed during the Second World War. Moreover, its adoption marked a crucial step towards developing international human rights and international criminal law. According to the Genocide Convention, genocide is a crime that can take place both in times of war and in the time of peace. The definition of the crime of genocide, as set out in the Convention, has been widely adopted at both national and international levels, including in the 1998 Rome Statute of the International Criminal Court (ICC). Notably, the Convention establishes on State Parties the obligation to take measures to prevent and punish the crime of genocide, including by enacting relevant legislation and punishing perpetrators, "whether they are constitutionally responsible rulers, public officials or private individuals" (Article IV). Along with the prohibition against genocide, this obligation has been regarded as a norm of international customary law and thus binding on all States, regardless of whether they have ratified the Genocide Convention. ${ }^{11}$

The Genocide Convention entered into force on 12 January 1951. The Convention has 42 Signatories and 152 Parties. ${ }^{12}$ According to the UN register, Turkey accessed the Genocide Convention on $31 \mathrm{Jul}$ 1950. As per the UN registry, Turkey did not make a reservation while becoming a party to the Convention. According to the UN registry, one of the countries that made the most prolonged reservation to the Convention is the USA. Per the UN registry, the US has made two reservations and made lengthy statements of understanding. One of the US reservations is as follows: "That nothing in the Convention requires or authorizes legislation or other action by the United States of America prohibited by the

7 Cooper, Raphael Lemkin and the Struggle for the Genocide Convention, 78.

8 UN General Assembly, "The Crime of Genocide" (UN General Assembly, December 11, 1946), A/RES/96, https://www.refworld.org/docid/3b00f09753.html.

9 UN General Assembly. A/RES/3/260. https://undocs.org/en/A/RES/260(III)

10 United Nations, "Convention on the Prevention and Punishment of the Crime of Genocide" (UN General Assembly, December 9, 1948), https://www.refworld.org/docid/3ae6b3ac0.html.

11 United Nations, "United Nations Office on Genocide Prevention and the Responsibility to Protect, Legal Framework, The Genocide Convention" (United Nations, December 9, 1948), A/RES/3/260, https://www.un.org/en/genocideprevention/genocide-convention.shtml.

12 United Nations, "Convention on the Prevention and Punishment of the Crime of Genocide : Chapter IV Human Rights" (United Nation, December 9, 1948), 12 January 1951, No. 1021, https://treaties.un.org/pages/ViewDetails.aspx?src=IND\&mtdsg no=IV-1\&chapter=4\&clang= en. 


\title{
DEGENERATING DISCURSIVE ATTEMPTS IN THE BALKANS TO ALTER THE LEGAL DEFINITION AND CONTENT OF THE CONCEPT OF GENOCIDE
}

Constitution of the United States as interpreted by the United States." The US reservations and understandings are presented in full text in footnote thirteen below for easy reference. ${ }^{13}$

On the other hand, academic sources state that Lemkin attaches foremost importance to Turkey being among the first twenty countries ratified the Genocide Convention. These sources note that Lemkin met with Turkey's Washington Embassy Counsellor Adnan Kural for this purpose and conveyed his thoughts on the matter. They also state that Lemkin later met with Turkey's Permanent Representative to the UN, Ambassador Selim Sarper, on the same issue and afterward included this meeting in his memoirs. An academic source reflects this issue as follows:

\begin{abstract}
"Although in his memoirs Lemkin made much of his friendly reception by a junior official at the Turkish embassy in November 1949, the really significant meeting happened the next day. Lemkin called on the Turkish Ambassador to the United Nations, Selim Sarper, and repeated the gist of his previous conversation and secured a promise from him to send a cable to his government urging ratification of the convention. On 4 May 1950, Lemkin wrote to Sarper that 'I received the good news from your office that the Parliament of Turkey ratified the Genocide Convention on March 29 before its dissolution ... I wish to thank you whole-heartedly for your leadership and also for your great personal kindness to me'." 14
\end{abstract}

As briefly explained above, the concept of genocide, which Lemkin brought to the agenda and tried to make it an international crime, was fully established on a legal basis by adopting the legally binding Genocide Convention. In this context, genocide is a notion that can be subject neither to political considerations nor to arbitrary demands. In other words, the Genocide Convention should not be eroded, and the term genocide, which has a strict legal definition, should not be used randomly. ${ }^{15}$ But, unfortunately, we have observed that some authorities, who want to do the opposite of what we have mentioned, have recently made dangerous statements that will erode the genocide convention, especially in the Balkans, and want to evolve the concept of genocide into different dimensions.

13 US Reservations:

"(1) That with reference to article IX of the Convention, before any dispute to which the United States is a party may be submitted to the jurisdiction of the International Court of Justice under this article, the specific consent of the United States is required in each case.

(2) That nothing in the Convention requires or authorizes legislation or other action by the United States of America prohibited by the Constitution of the United States as interpreted by the United States."

Understandings:

“(1) That the term 'intent to destroy, in whole or in part, a national, ethnical, racial, or religious group as such' appearing in article II means the specific intent to destroy, in whole or in substantial part, a national, ethnical, racial or religious group as such by the acts specified in article II.

(2) That the term 'mental harm' in article II (b) means permanent impairment of mental faculties through drugs, torture or similar techniques.

(3) That the pledge to grant extradition in accordance with a state's laws and treaties in force found in article VII extends only to acts which are criminal under the laws of both the requesting and the requested state and nothing in article VI affects the right of any state to bring to trial before its own tribunals any of its nationals for acts committed outside a state.

(4) That acts in the course of armed conflicts committed without the specific intent required by article II are not sufficient to constitute genocide as defined by this Convention.

(5) That with regard to the reference to an international penal tribunal in article VI of the Convention, the United States declares that it reserves the right to effect its participation in any such tribunal only by a treaty entered into specifically for that purpose with the advice and consent of the Senate." Source: United Nations.

14 Cooper, regarding these meetings refers to the following two sources: "Lemkin, Autobiography, chapter entitled 'Climbing a Mountain Again', pp. 312; Raphael Lemkin to Selim Sarper, 4 May 1949, Lemkin Papers, Box 1/15 American Jewish Archives." Source: Cooper, Raphael Lemkin and the Struggle for the Genocide Convention, 184,312.

15 Republic of Turkey Ministry of Foreign Affairs, "No: 410, 9 December 2021, Press Release Regarding the International Day of Commemoration and Dignity of the Victims of the Crime of Genocide and of the Prevention of This Crime" (Republic of Turkey Ministry of Foreign Affairs, December 9, 2021), 410, Press Release No: 410, https://www.mfa.gov.tr/no_-410_-soykirim-sucu-magdurlarini-anma-ve-onurlandirma-ve-bu-sucun-onlenmesiuluslararasi-gunu-hk.en.mfa. 


\section{Statements by the President of Croatia downplaying the Srebrenica Genocide}

President of Croatia, Zoran Milanovic, according to reports of various media outlets, speaking to the press in the city of Komija on the Croatian island of Vis, answering a question on whether he considered Srebrenica a genocide, recently said the following:

"I say yes, but then for some more serious crimes, we have to invent another name. I respect other people's sacrifices, but not everything is the same. If everything is genocide, we will have to find another name for what the Nazis and the German machinery did to the Jews in the Second World War. It is the Holocaust, but it is also genocide. Not every victim is the same, it is relativization." 16

In addition to these remarks, it is reported in the Croatian online newspaper "Index.hr" that he also touched on Vukovar and Ovcara and said that "Is Vukovar genocide? We never say in Croatia that it is genocide, probably because we have some measure. But Vukovar was systematically destroyed in two months. The city and the people. The target was Croats and some Serbs who remained with Croats in basements. And finally Ovcara, are there any elements to talk about genocide? " 17 As per Euractiv media network, Zoran Milanovic also said that "there are genocides and genocides. There is genocide against Jewish peoples, in Rwanda, there is genocide in Srebrenica, i.e., one event defined as genocide, and genocide has an extensive range, there is genocide in World War II, there is Jasenovac ${ }^{18} \ldots$ Not everything is the same, just as every victim is not the same. It is best to say that everything is the same. It is not." 19

Balkan Insight website of the Balkan Investigative Reporting Network (BIRN) that focuses on news, analysis, commentary, and investigative reporting from southeast Europe ${ }^{20}$ reflects and analyzes this statement of Croatian President Zoran Milanovic with the title "shooting from the hip." Before examining these statements, which have content that is very compatible with the phrase "shooting/firing from the hip", we consider that it would be helpful to have information about Zoran Milanović's biography.

According to his formal biography, Zoran Milanović graduated from the University of Zagreb Law Faculty. In 1998, he earned a master's degree in European Union Law at the Flemish University in Brussels (V.U.B.). He started his professional career as an intern at the Zagreb Commercial Court, and in 1993 he joined the Croatian Ministry of Foreign Affairs. He was a political advisor to the OSCE peacekeeping mission in Azerbaijan in 1994, and from 1996 to 1999, he served as an advisor at the Croatian mission to the European Union and NATO in Brussels. In 2003, he became the Assistant Minister for Political Multilateral Affairs at the Ministry of Foreign Affairs. In 2007 he was elected President of the Social Democratic Party of Croatia and in 2011 became the Prime Minister of the 10th

16 Mustafa Talha Öztürk, “Croatian President Makes Controversial Statements on Srebrenica Genocide,” Anadolu News Agency, December 9, 2021, sec. Europe, https://www.aa.com.tr/en/europe/croatian-president-makes-controversial-statements-on-srebrenica-genocide/2442617; "Croatian President Condemned for Downplaying Srebrenica Genocide," TRT World, December 7, 2021, sec. News/Magazine, https://www.trtworld.com/magazine/croatianpresident-condemned-for-downplaying-srebrenica-genocide-52403; Sven Milekic, "Shooting from the Hip, Croatian President Makes Play for New Base," Balkan Insight, December 9, 2021, sec. Opinion, https://balkaninsight.com/2021/12/09/shooting-from-the-hip-croatian-president-makes-playfor-new-base/; Zeljko Trkanjec, "Bosniak Leader in Croatia: President's Srebrenica Statement Crossed a Red Line - EURACTIV.Com," Euractiv, December 6, 2021, sec. The Capitals, https:/www.euractiv.com/section/politics/short_news/bosniak-leader-in-croatia-presidents-srebrenica-statementcrossed-a-red-line/.

17 Hina, "Milanović: Mi u Hrvatskoj ne govorimo da je u Vukovaru bio genocid, imamo neku mjeru," index.hr, December 6, 2021, sec. Hrvatska, https://www.index.hr/clanak.aspx?id=2323673.

18 Jasenovac was a concentration and extermination camp established in the village of the same name by the authorities of the Independent State of Croatia (NDH) in occupied Yugoslavia during World War II.

19 Trkanjec, "Bosniak Leader in Croatia: President's Srebrenica Statement Crossed a Red Line - EURACTIV.Com."

20 According to website of BIRN, donors to the Balkan Investigative Reporting Network include the Austrian Development Agency (ADA), The Balkan Trust for Democracy (BTD), The Delegation of the European Union to Montenegro, ERSTE Foundation, The European Commission (EC), The KonradAdenauer-Stiftung (KAS), Rockefeller Brothers Fund, The Dutch Fund for Regional Partnerships/Matra, The Swedish International Development Cooperation Agency (Sida), available at: Balkan Insight, "Donors,” Online News Portal, Balkan Insight, 2007, https://balkaninsight.com/donors/. 


\section{DEGENERATING DISCURSIVE ATTEMPTS IN THE BALKANS TO ALTER THE LEGAL DEFINITION AND CONTENT OF THE CONCEPT OF GENOCIDE}

Croatian Government. He ran for and won the 20192020 presidential elections, thus becoming the fifth President of the Republic of Croatia. ${ }^{21}$

The main reason we are trespassing our readers' valuable time by giving this background information in such detail is to reveal that a head of state who made the above statements, besides being a lawyer and diplomat, also serves for organizations such as the OSCE, NATO, and the EU.

\section{The errors, omissions, and the ulterior motive in the statements of Zoran Milanović}

In his statements, Zoran Milanovic, firstly, infelicitously draws analogies and makes comparisons between the Holocaust and the Srebrenica genocide. While making this comparison, he does not mention that the Holocaust took place during the Second World War period that the officials of Nazi Germany were convicted by the International Military Tribunal in Nuremberg in 1946, and that the genocide convention was prepared at the UN after the Second World War and was adopted in the UN in 1948. That is, he is confusing apples with oranges which cannot be practically compared because of inherent fundamental differences in the legal framework between the Holocaust and the genocide crimes.

Secondly, Milanovic asks a question that "Is Vukovar genocide?" and then he answers his question as "We never say in Croatia that it is genocide probably because we have some measure." Milanovic, however, does not refer to the Croatian genocide lawsuit against Serbia - with the alleged crimes committed in Vukovar as its crucial argument - before the International Court of Justice and lost.

As it will be recalled, on 2 July 1999, Croatia filed an Application against the Federal Republic of Yugoslavia (FRY) "for violations of the Convention on the Prevention and Punishment of the Crime of Genocide". On 4 January 2010, the Republic of Serbia filed its Counter-Memorial containing counterclaims. The Court held public hearings from 3 March to 1 April 2014, at which time it also heard witnesses and witness experts. The Court delivered its Judgment on 3 February 2015. The Court found that the intentional element of genocide (dolus specialis) is lacking and accordingly rejected Croatia's claim in its entirety. In the same fashion, the Court found that the intentional element of genocide (dolus specialis) is lacking and accordingly also rejected Serbia's counter-claim in its entirety. ${ }^{22}$ This decision of the ICJ is a prime example of how the genocide was determined by an internationally authorized court, how each piece of evidence was examined in detail, and how the genocide decision was reached. In this context, it is an example that shows that political statements to be made to the press in haste on the decisions regarding the crime of genocide are of no value.

Thirdly, Zoran Milanovic, off the cuff, grades the crime of genocide, claims that not every genocide is the same and proposes that new names should be found for such crimes within the framework of his personal rating system. It is not possible to guess whether he made this proposal off the cuff or as a result of long and hard thinking. However, when one hears these bright ideas, the first thing that comes to mind is the rhetoric Lemkin used when he first mentioned the concept of genocide, which is "A new Term and New Conceptions for Destruction of Nations." Considering that certain EU countries have been recently bringing up revisionist views and suggestions regarding the Balkans, we cannot ignore the possibility that Milanovic will jump on the bandwagon of producing "brilliant" ideas. In this context, it suffices to recall the Slovenian Prime Minister's plan (as the Slovenian EU presidency) to dismember Bosnia and Herzegovina, reorganize the borders of Croatia, Serbia, Albania, and Kosovo. ${ }^{23}$ As it will be

21 Republic of Croatia, "Biography Of Zoran Milanović," Government, The President President of the Republic of Croatia, 2020, https://www.predsjednik.hr/en/president/.

22 International Court Of Justice, "Application of the Convention on the Prevention and Punishment of the Crime of Genocide (Croatia v. Serbia)" (International Court Of Justice, February 3, 2015), No. 2015/4, https://www.icj-cij.org/public/files/case-related/118/18448.pdf.

23 Teoman Ertuğrul Tulun, "Slovenian Document On Dismemberment Of Bosnia-Herzegovina Confirms The Necessity Of Continuing The PIC-OHRBonn Powers," Center For Eurasian Studies Analysis Series 2021, no. 18 (April 30, 2021): 6, https://doi.org/10.31219/osf.io/xpwhb. 
recalled, this plan contained the following proposal: "The Croatian national issue can be resolved by joining the predominantly Croatian cantons in the Bosnia-Herzegovina with Croatia or by granting special status to Croatian part of Bosnia-Herzegovina (using South Tyrol as a method)".

\section{Conclusion}

There has been a significant increase in revisionist discourses in the Balkans recently. The statements of Croatian President Zoran Milanovic on the Srebrenica genocide are an example of such discourses. The statements of Milanovic in this respect are also noteworthy in that they seriously question the current legal basis and framework of the crime of genocide. These statements will inevitably have repercussions both in the Balkans and internationally. It should be noted that any misuse of the term genocide based on shallow political interests will constitute an utter disservice to the fundamental principles of maintaining international peace, security, and stability as enshrined in the UN Charter. ${ }^{24}$ In terms of the Balkans, as mentioned above, it is noteworthy that revisionist discourses have recently come from countries such as Slovenia and Croatia, which are both NATO and EU members. It is disappointing that these countries, instead of playing a role that strengthens security and stability in the Balkans, play a role that disrupts security and stability. Member states of these influential international and supranational organizations are naturally expected to be much more careful in ensuring and maintaining security and stability in the Balkans. If there is a danger of fire in an area, instead of throwing flammable materials into the area, it is necessary to try to prevent the fire hazard. As AVIM, we hope that rhetoric and policies to the contrary will not be accepted in both NATO and the EU.

24 Republic of Turkey Ministry of Foreign Affairs, "No: 410, 9 December 2021, Press Release Regarding the International Day of Commemoration and Dignity of the Victims of the Crime of Genocide and of the Prevention of This Crime," 410. 


\section{Bibliography:}

Balkan Insight. "Donors.” Online News Portal. Balkan Insight, 2007. https://balkaninsight.com/donors/.

Cooper, J. Raphael Lemkin and the Struggle for the Genocide Convention. 2008th edition. Basingstoke England ; New York: Palgrave Macmillan, 2008.

"Croatian President Condemned for Downplaying Srebrenica Genocide." TRT World, December 7, 2021, sec. News/Magazine. https://www.trtworld.com/magazine/croatian-president-condemned-fordownplaying-srebrenica-genocide-52403.

Hina. "Milanović: Mi u Hrvatskoj ne govorimo da je u Vukovaru bio genocid, imamo neku mjeru." index.hr, December 6, 2021, sec. Hrvatska. https://www.index.hr/clanak.aspx?id=2323673.

International Court Of Justice. "Application of the Convention on the Prevention and Punishment of the Crime of Genocide (Croatia v. Serbia).” International Court Of Justice, February 3, 2015. No. 2015/4. https://www.icj-cij.org/public/files/case-related/118/18448.pdf.

Lemkin, Raphael, William A. Schabas, and Samantha Power. Axis Rule in Occupied Europe: Laws of Occupation, Analysis of Government, Proposals for Redress. 2nd edition. Clark, N.J: The Lawbook Exchange, Ltd., 2008.

Milekic, Sven. "Shooting from the Hip, Croatian President Makes Play for New Base." Balkan Insight. December 9, 2021, sec. Opinion. https://balkaninsight.com/2021/12/09/shooting-from-the-hipcroatian-president-makes-play-for-new-base/.

Öztürk, Mustafa Talha. "Croatian President Makes Controversial Statements on Srebrenica Genocide." Anadolu News Agency. December 9, 2021, sec. Europe. https:/www.aa.com.tr/en/europe/croatianpresident-makes-controversial-statements-on-srebrenica-genocide/2442617.

Power, Samantha. A Problem from Hell: America and the Age of Genocide. New York: HarperCollins, 2007.

Republic of Croatia. "Biography Of Zoran Milanović." Government. The President President of the Republic of Croatia, 2020. https://www.predsjednik.hr/en/president/.

Republic of Turkey Ministry of Foreign Affairs. "No: 410, 9 December 2021, Press Release Regarding the International Day of Commemoration and Dignity of the Victims of the Crime of Genocide and of the Prevention of This Crime." Republic of Turkey Ministry of Foreign Affairs, December 9, 2021. Press Release No: 410. https://www.mfa.gov.tr/no_-410_-soykirim-sucu-magdurlarini-anma-veonurlandirma-ve-bu-sucun-onlenmesi-uluslararasi-gunu-hk.en.mfa.

Trkanjec, Zeljko. "Bosniak Leader in Croatia: President's Srebrenica Statement Crossed a Red Line EURACTIV.Com." Euractiv, December 6, 2021, sec. The Capitals.

https://www.euractiv.com/section/politics/short_news/bosniak-leader-in-croatia-presidents-srebrenicastatement-crossed-a-red-line/.

Tulun, Teoman Ertuğrul. "Slovenian Document On Dismemberment Of Bosnia-Herzegovina Confirms The Necessity Of Continuing The PIC-OHR-Bonn Powers." Center For Eurasian Studies Analysis Series 2021, no. 18 (April 30, 2021): 6. https://doi.org/10.31219/osf.io/xpwhb.

UN General Assembly. "The Crime of Genocide." UN General Assembly, December 11, 1946. A/RES/96. https://www.refworld.org/docid/3b00f09753.html. 
United Nations. "Convention on the Prevention and Punishment of the Crime of Genocide." UN General Assembly, December 9, 1948. https://www.refworld.org/docid/3ae6b3ac0.html.

"Convention on the Prevention and Punishment of the Crime of Genocide : Chapter IV Human Rights." United Nation, December 9, 1948. 12 January 1951, No. 1021.

https://treaties.un.org/pages/ViewDetails.aspx?src=IND\&mtdsg_no=IV-1\&chapter=4\&clang=_en.

"United Nations Office on Genocide Prevention and the Responsibility to Protect, Legal Framework, The Genocide Convention." United Nations, December 9, 1948. A/RES/3/260. https://www.un.org/en/genocideprevention/genocide-convention.shtml.

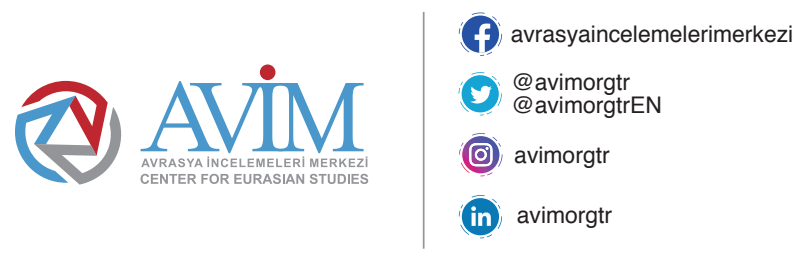

